\title{
MENINGKATKAN PERKEMBANGAN KOGNITIF DENGAN METODE BERNYANYI PADA ANAK USIA DINI
}

\author{
Nur Risma Khafifah ${ }^{{ }^{*}}$, Nana ${ }^{2}$ \\ ${ }^{7}$ Mahasiswa Program Studi Pendidikan Fisika, Universitas Siliwangi \\ ${ }^{2}$ Dosen Program Studi Pendidikan Fisika, Universitas Siliwangi \\ `e-mail korespondensi: nurrisma8816@gmail.com
}

\begin{abstract}
The purpose of this study was to determine the effect of singing on the cognitive abilities of group B children at TK Hati Hati Aisyiyah Kindergarten, Tasikmalaya City in the academic year 2019/2020. This research is an experimental research. The experimental design used was pre-experimental design type one group pretest-posttest design. The subjects in this study were group $B$ with a total of 15 children. The cognitive ability data collection technique used is observation. Data analysis techniques using t-test. The results obtained by the cognitive abilities of children of group $B$ at an average pretest score of 7, 4 and posttest average score of 11.46. The results of the $t$ test data analysis showed that the tcount was $-61,000 \leq-t$ table 1,761. This shows that $\mathrm{HO}$ was rejected and Ha was accepted. The conclusion of this research is singing affects the cognitive abilities of group B children in Permata Hati Aisyiyah Kindergarten in Tasikmalaya City in the academic year 2019/2020.
\end{abstract}

Keywords: Singing Method, Cognitive Development

\begin{abstract}
Abstrak : Tujuan penelitian ini adalah mengetahui pengaruh bernyanyi terhadap kemampuan kognitif anak kelompok B di TK Permata Hati Aisyiyah Kota Tasikmalaya tahun pelajaran 2019/2020. Penelitian ini merupakan penelitian eksperimen. Desain eksperimen yang digunakan yaitu pre-eksperimental design jenis one group pretest- posttest design. Subjek dalam penelitian ini adalah kelompok B yang berjumlah 15 anak. Teknik pengumpulan data kemampuan kognitif yang digunakan adalah observasi. Teknik analisis data menggunakan $\mathrm{t}-$ test. Hasil penelitian diperoleh kemampuan kognitif anak kelompok B pada pretest skor rata-rata 7, 4 dan posttest skor rata-rata 11,46. Hasil analisis data uji t diperoleh bahwa thitung $-61,000 \leq-$ tabel 1,761. Hal ini menunjukkan bahwa HO ditolak dan $\mathrm{Ha}$ diterima. Kesimpulan penelitian ini adalah bernyanyi berpengaruh terhadap kemampuan kognitif anak kelompok B di TK Permata Hati Aisyiyah Kota Tasikmalaya tahun pelajaran 2019/2020.
\end{abstract}

Kata Kunci: Metode Bernyanyi, Perkembangan Kognitif

\section{Pendahuluan}

Pendidikan Anak Usia Dini (PAUD) adalah suatu upaya pembinaan yang ditujukan melalui pemberian 
rangsangan pendidikan untuk membantu pertumbuhan dan perkembangan jasmani dan rohani agar anak memiliki kesiapan dalam memasuki pendidikan lebih lanjut (Undang-undang Nomor 20 Tahun 2003 tentang Sistem Pendidikan Nasional).

Pendidikan Anak Usia Dini (PAUD) merupakan pendidikan yang paling mendasar menempati posisi yang sangat strategis dalam pengembangan sumber daya manusia (Depdiknas, 2005:1).

Anak usia dini adalah anak yang berada pada rentang usia lahir sampai dengan enam tahun merupakan rentang usia kritis dan sekaligus strategis maka diperlukan proses pendidikan yang dapat mempengaruhi proses serta hasil pendidikan pada tahap selanjutnya.

Sebagai salah satu bagian dari pendidikan anak usia dini jalur pendidikan formal, Taman Kanakkanak memiliki tugas mulia untuk mengembangkan berbagai kemampuan dasar peserta didik yang terkait dengan aspek sosial, emosional, fisik, kognitif, bahasa, dan estetika. Kegiatan pembelajaran di Taman Kanak-kanak diharapkan mampu memberikan rangsangan dan motivasi belajar sehingga potensi

peserta didik dapat berkembang secara optimal.

Sudjana dalam Nana (2019:2) menjelaskan bahwa berhasil atau tidaknya proses belajar mengajar dapat dilihat dari hasil belajarnya. Hasil proses belajar tersebut dapat dinilai melalui evaluasi hasil belajar. Klasifikasi hasil belajar, secara garis besar dibagi menjadi tiga ranah, yaitu: (1) ranah kognitif, (2) ranah afektif, (3) ranah psikomotor.

Dari aspek pendidikan, stimulasi dini sangat diperlukan guna memberikan rangsangan terhadap seluruh aspek perkembangan anak, yang mencakup penanaman nilai-nilai dasar (agama dan budi pekerti), pembentukan sikap (disiplin dan kemandirian), dan pengembangan kemampuan dasar (berbahasa, motorik, kognitif dan sosial). Salah satu bentuk kemampuan dasar yang harus dikembangkan pada anak usia dini adalah kemampuan kognitif. Kognitif adalah aktivitas yang berhubungan dengan pola pikir atau mental seseorang.

Untuk hal tersebut, dibutuhkan kegiatan yang dapat merangsang kemampuan kognitif anak seperti stimulasi dan bimbingan, yang akan meningkatkan perkembangan berpikir anak sehingga menjadi dasar utama 
untuk perkembangan anak yang selanjutnya serta didukung oleh media -media yang kreatif untuk menciptakan pembelajaran yang inovatif.

Dalam pengembangan kognitif banyak sekali kegiatan yang dapat dilakukan guru dalam mengembangkan aspek kemampuan kognitif anak di antaranya adalah melalui kegiatan bernyanyi, bercerita, dan masih banyak lagi yang lainnya. Dari berbagai macam kegiatan tersebut, bernyanyi sampai saat ini hanya dianggap sebagai suatu indikator yang tidak penting. Padahal dalam setiap lagu memiliki makna dan manfaat dalam pengembangan segala aspek, baik dari segi pembiasaan, kognitif, bahasa, seni, maupun fisik motorik, karena dalam proses penyampaian materi di taman kanakkanak tidak hanya terpaku pada kegiatan yang dilakukan melalui penjabaran, penjelasan di kelas atau pemberian tugas, tapi juga berupa bermain dan bernyanyi.

Dalam sebuah lagu kita dapat menyampaikan cerita atau dongeng, nasihat, pengetahuan dan juga berbagai ilmu. Kondisi pembelajaran bernyanyi di taman kanak-kanak saat ini mengalami banyak kendala baik terbatasnya buku sumber, tidak adanya musik pengiring untuk lagulagu tertentu, termasuk kesibukan dari guru itu sendiri, sehingga banyak ditemukan kesalahan-kesalahan dalam penyampaian nyanyian. Kesalahan-kesalahan penyampaian nyanyian tersebut menyebabkan manfaat dari bernyanyi bagi pertumbuhan dan perkembangan anak menjadi tidak efektif. Sehingga bernyanyi hanya akan menjadi pengisi waktu luang atau menghabiskan waktu secara percuma.

Bernyanyi berbeda dengan berbicara, bernyanyi memerlukan teknik-teknik tertentu sedangkan berbicara tanpa perlu menggunakan teknik tertentu. Bagi anak kegiatan bernyanyi adalah kegiatan menyenangkan bagi mereka dan pengalaman bernyanyi memberikan kepuasan kepadanya, bernyanyi juga merupakan alat bagi anak untuk mengungkapkan perasaan dan pikirannya. Semua kegiatan belajar ini dikemas dalam model belajar sambil bernyanyi.

Kenyataan di lapangan, di sekolah sudah menggunakan kegiatankegiatan dalam mengembangkan kemampuan kognitif tersebut, tetapi dalam bernyanyi hanya sebatas untuk menghibur anak, dikala anak jenuh dalam proses pembelajaran tanpa 
menekankan pada kemampuan kognitif anak seperti menjelaskan kata-kata sukar pada nyanyi dan mengabaikan makna dari kata-kata tersebut kepada anak. Seharusnya bernyanyi itu berperan penting dalam pengembangan kognitif anak karena melalui bernyanyi anak bisa secara langsung mengucapkan kata demi kata dan meningkatkan daya pikir sehingga anak lebih mudah mengingat dan mengungkapkan apa yang dirasakannya melalui nyanyian anak akan di ajak mengetahui kata-kata sukar pada nyanyi tersebut serta makna dari nyanyi tersebut.

Peneliti memandang bahwa kegiatan bernyanyi memiliki peranan penting dalam kemampuan kognitif anak. Berangkat dari pemikiran inilah peneliti ingin mengetahui lebih jauh tentang

"Meningkatkan

Perkembangan Kognitif dengan Metode Bernyanyi pada Anak Usia Dini di TK Permata Hati Aisyiyah Kota Tasikmalaya".

Banyak ahli yang menjelaskan definisi kemampuan. Wijaya (1992: 8) menjelaskan,

"Kemampuan merupakan kesanggupan menyelesaikan suatu hal dengan baik". Sejalan dengan pendapat Wijaya, Sujono dkk (2006: 14) menjelaskan, "Kemampuan merupakan perilaku yang rasional untuk mencapai tujuan yang disyaratkan sesuai dengan kondisi yang diharapkan".

Beberapa ahli psikologi yang berkecimpung dalam bidang pendidikan mendefinisikan intelektual atau kognitif dengan berbagai peristilahan. Kognitif adalah kemampuan untuk berpikir secara abstrak. Kognitif adalah kemampuan menyesuaikan diri dengan lingkungan. Kognitif adalah teknik untuk memproses informasi yang disediakan oleh indra intelektual ditambah dengan pengetahuan. Gagne dalam (Jamaris, 2008: 2) menjelaskan "Kognitif adalah proses yang terjadi secara internal di dalam pusat susunan saraf pada waktu manusia sedang berpikir".

Dari beberapa pendapat para ahli di atas dapat disimpulkan bahwa kognitif adalah suatu proses berpikir, yaitu kemampuan individu untuk menghubungkan, menilai, dan mempertimbangkan suatu kejadian atau peristiwa. Kemampuan kognitif ini berkembang secara bertahap sejalan dengan perkembangan fisik dan saraf-saraf yang berada di pusat susunan saraf terkait.

Ciri-ciri perilaku kognitif yaitu berpikir lancar, luwes, orisinal dan berpikir terperinci. Faktor yang 
mempengaruhi adalah hereditas, lingkungan, kematangan, pembentukan, minat dan kebebasan.

Indikator kemampuan kognitif yang digunakan peneliti adalah Menyebutkan nama-nama hari dalam satu minggu, satu bulan dan mengetahui jumlah bulan dalam satu tahun, dan Menyampaikan tentang apa dan bagaimana benda-benda di sekitar yang dikenalnya (nama, warna, bentuk, ukuran, pola, sifat, tekstur, fungsi dan ciri-ciri lainnya. Indikator tersebut berdasarkan Permendikbud No. 137 Tahun 2014 Tentang Standar Nasional Pendidikan Anak Usia Dini.

Bernyanyi berasal dari kata "Nyanyi" yang berimbuhan "ber" yang artinya melafalkan syair sesuai nada, ritme, dan melodi tertentu hingga membentuk harmoni. Jamalus (1998: 46) menjelaskan, "Kegiatan bernyanyi adalah merupakan kegiatan di mana kita mengeluarkan suara secara beraturan dan berirama baik diiringi oleh iringan musik ataupun tanpa iringan musik.

\section{Kamtini} (2005: mengemukakan, "Bernyanyi merupakan sarana pengungkapan pikiran dan perasaan, sebab kegiatan bernyanyi penting bagi pendidikan anak-anak selain itu bernyanyi adalah kegiatan menyenangkan yang memberi kepuasan kepada anak- anak . Sejalan dengan dua ahli di atas, Masitoh, dkk (2007:11.8) mengemukakan, "Bernyanyi pada dasarnya merupakan bakat alamiah yang dimiliki oleh seorang individu. Sejak lahir bayi telah mulai mengenal suara, ritme atau melodi melalui lagu yang dilantunkan oleh ibunya. Di taman kanak-kanak bernyanyi merupakan kegiatan yang dapat di integrasikan dalam

Pembelajaran."

Melalui nyanyian atau lagu, banyak hal yang dapat kita pesankan kepada anak-anak, terutama pesan-pesan moral dan nilai-nilai agama. Dengan kegiatan bernyanyi, suasana pembelajaran akan lebih menyenangkan, menggairahkan, membuat anak bahagia, menghilangkan rasa sedih, anak-anak merasa terhibur, dan lebih bersemangat. Dengan bernyanyi potensi belahan otak kanan dapat dioptimalkan, sehingga pesan-pesan yang kita berikan akan lebih lama mengendap di memori anak (ingatan jangka panjang).

Dengan demikian anak akan selalu ingat pesan-pesan yang diterimanya. Fungsi Bernyanyi menurut Kamtini (2005:118) yaitu:

a. Menambah perbendaharaan 
bahasa, berbuat kreatif, berimajinasi.

b. Bermain bersama, mematuhi aturan permainan, tidak mementingkan diri sendiri (sosial).

c. Menyalurkan emosi ,menimbulkan rasa senang (emosi).

d. Melatih otot badan, mengkoordinasikan gerak tubuh (psikomotorik).

Berdasarkan kajian teori di atas dapat diajukan hipotesis "Bernyanyi Berpengaruh Positif Terhadap Kemampuan Kognitif Anak TK Permata Hati Aisyiyah Kota Tasikmalaya".

\section{Metode Penelitian}

Penelitian ini menggunakan PreEksperimen Design yaitu dengan one group Pretest Posttest Design sebagai desain penelitian. Pada design ini terdapat pretest sebelum diberikan perlakuan dan prostates setelah diberikan perlakuan. Design penelitian ini diketahui lebih akurat karena dapat membandingkan sebelum diberi perlakuan dengan hasil perlakuan.

Penelitian ini dilakukan selama bulan Januari 2019 Subjeknya anak kelompok $B$ yang berjumlah 15 anak. Teknik pengumpulan data yang digunakan dalam penelitian ini adalah observasi.
Sutrisno Hadi dalam Sugiyono (2011:145) menjelaskan, “Observasi merupakan suatu proses yang kompleks, suatu proses yang tersusun dari berbagai proses biologis dan psikologis".

Untuk mencatat hasil observasi peneliti menggunakan cek list dan rating scale. Chek list atau daftar cek adalah pedoman observasi yang berisikan daftar dari semua aspek yang diamati, msedangkan rating scale adalah instrument observasi yang berisi tentang segala aspek yang diobservasi yang dikategorikan dalam bentuk skala yang dijadikan pedoman oleh observasi untuk menentukan rentangan beberapa aspek yang diobservasi itu kira-kira berbeda.

Data yang telah didapat kemudian dianalisis menggunakan teknik analisis uji-t. Uji-t digunakan untuk mengetahui signifikasi pengaruh variabel bebas yaitu bernyanyi $(X)$ terhadap variabel terikat yaitu perkembangan kognitif $(Y)$ dengan membandingkan keadaan awal (sebelum diberi perlakuan) dan keadaan akhir (setelah diberi perlakuan), sehingga bisa diketahui apakah dugaan yang sudah ada dapat diterima atau ditolak.

\section{Hasil dan Pembahasan}


Sebelum peneliti melakukan eksperimen, dilaksanakan tahap praeksperimen. Hasil penelitian tersebut penulis sajikan dalam tabel berikut.

Tabel 1. Kemampuan Kognitif anak kelompok B di TK Permata Hati Aisyiyah Kota Tasikmalaya tahun pelajaran 2019/2020 sebelum eksperimen

\begin{tabular}{|c|c|c|c|}
\hline \multirow{2}{*}{ Interval } & \multicolumn{2}{|c|}{ Sebelum Eksperimen } & \multirow{2}{*}{ Kategori } \\
\hline & $\begin{array}{l}\text { Frekuens } \\
\text { i }\end{array}$ & $\begin{array}{l}\text { Persentas } \\
\mathrm{e}\end{array}$ & \\
\hline$X<6$ & 3 & 20 & $\begin{array}{l}\text { Belum } \\
\text { Berkemban } \\
\mathrm{g}\end{array}$ \\
\hline$X<6$ & 8 & 53 & $\begin{array}{l}\text { Mulai } \\
\text { Berkemban } \\
\text { g }\end{array}$ \\
\hline $9 \geq x<12$ & 4 & 27 & $\begin{array}{l}\text { Berkemban } \\
\mathrm{g} \\
\text { Sesuai } \\
\text { Harapan }\end{array}$ \\
\hline$x \geq 12$ & - & 0 & $\begin{array}{l}\text { Berkemban } \\
\mathrm{g} \\
\text { Sangat } \\
\text { Baik }\end{array}$ \\
\hline Jumlah & 15 & 100 & \\
\hline
\end{tabular}

Tabel 1 di atas menunjukkan bahwa sebelum dilakukan eksperimen terdapat tiga anak yang memiliki kemampuan kognitif dengan kategori belum berkembang, delapan anak yang memiliki

kemampuan kognitif dengan kategori mulai berkembang, dan empat anak memiliki kemampuan kognitif dengan kategori berkembang sesuai harapan. Sehingga rata-rata skor kemampuan kognitif anak sebelum eksperimen adalah mulai berkembang dengan persentase $53 \%$.

Tabel 2. Kemampuan Kognitif anak kelompok B di TK Permata Hati Aisyiyah Kota Tasikmalaya tahun pelajaran 2019/2020 setelah eksperimen

\begin{tabular}{|c|c|c|c|}
\hline \multirow{2}{*}{ Interval } & \multicolumn{2}{|c|}{ Sebelum Eksperimen } & \multirow{2}{*}{ Kategori } \\
\hline & $\begin{array}{l}\text { Frekuens } \\
\text { i }\end{array}$ & $\begin{array}{l}\text { Persentas } \\
\mathrm{e}\end{array}$ & \\
\hline$X<6$ & - & & $\begin{array}{l}\text { Belum } \\
\text { Berkemban } \\
\mathrm{g}\end{array}$ \\
\hline$x<6$ & 1 & 7 & $\begin{array}{l}\text { Mulai } \\
\text { Berkemban } \\
\text { g }\end{array}$ \\
\hline $9 \geq x<12$ & 7 & 46 & $\begin{array}{l}\text { Berkemban } \\
\mathrm{g} \\
\text { Sesuai } \\
\text { Harapan }\end{array}$ \\
\hline$x \geq 12$ & 7 & 47 & $\begin{array}{l}\text { Berkemban } \\
\mathrm{g} \\
\text { Sangat } \\
\text { Baik }\end{array}$ \\
\hline Jumlah & 15 & 100 & \\
\hline
\end{tabular}


Tabel 2 di atas menjelaskan bahwa setelah eksperimen terdapat satu anak yang memiliki kemampuan kognitif dengan kategori mulai berkembang, tujuh anak yang memiliki kemampuan kognitif yang berkategori berkembang sesuai harapan, dan tujuh anak memiliki kemampuan kognitif dengan kategori

berkembang sangat baik. Sehingga rata-rata skor kemampuan kognitif anak setelah eksperimen adalah berkategori berkembang sesuai harapan dengan persentase $46 \%$.

Teknik analisis yang digunakan dalam penelitian ini adalah uji t. Berdasarkan hasil analisis diperoleh thitung $-61,000$. Dengan taraf signifikasi $1 \%$ dapat dilihat tabel $=2,624$, maka thitung $\leq-$ ttabel $^{-61,000} \leq-2,624$. Sedangkan dengan taraf signifikasi $5 \%$ dapat dilihat tabel $=1,761$, maka thitung $\leq$ - ttabel $-61,000 \leq-1,761$.

Hasil pengolahan data tersebut dapat disimpulkan dengan menentukan taraf signifikasi $1 \%$ maupun $5 \% \mathrm{HO}$ ditolak dan Ha diterima. Dengan kata lain, bernyanyi berpengaruh terhadap kemampuan kognitif anak pada kelompok B di TK Permata Hati Aisyiyah Kota Tasikmalaya.

Melalui bernyanyi suasana pembelajaran

anak

lebih

menyenangkan,

menggairahkan,

membuat anak

bahagia, menghilangkan rasa sedih, anak-anak merasa terhibur, dan lebih

bersemangat. Dengan bernyanyi potensi belahan otak kanan dapat dioptimalkan, sehingga pesan-pesan yang kita berikan akan lebih lama mengendap di memori anak (ingatan jangka panjang), dengan demikian anak akan selalu ingat kata demi kata yang diterimanya.

\section{Penutup}

Berdasarkan hasil penelitian yang telah dilakukan maka disimpulkan bahwa bernyanyi berpengaruh terhadap kemampuan kognitif anak kelompok B di TK Permata Hati Aisyiyah Kota Tasikmalaya.

\section{Referensi}

Jamaris, Martini.

(2008). Perkembangan dan Pengembangan Anak Usia Taman Kanak-kanak. Program Studi Pendidikan Anak Usia Dini: UNJ.

Kamtini, dkk. (2005). Bermain Melalui Gerak dan Lagu di Taman KanakKanak. Jakarta: Departemen Pendidikan Nasional

Masitoh, dkk, (2007). Strategi Pembelajaran TK. Jakarta. Universitas Terbuka.

Nana, N. (2019). Upaya Peningkatan 
Kemampuan Kognitif dan Komunikasi Ilmiah Siswa Kelas $X$ MIA 1 SMA Negeri 1 Ciamis Menggunakan Model Pembelajaran Inquiry. Diffraction Journal for Physics Education and Applied Physics. (pp 1-10).

Permendikbud No. 137 Tahun 2014 Tentang Standar Nasional Pendidikan Anak Usia Dini.

Samba, Sojono. (2006). Lebih Baik Tidak Sekolah. Yogyakarta. Lkis.

Undang Undang No. 20 Tahun 2003 tentang Sistem Pendidikan Nasional.

Wijaya, A. Cece. (1992). Kemampuan Dasar Guru dalam Proses Belajar Mengajar. Bandung: PT. Remaja Rosdakarya. 